\title{
Effect of Talus Deposit Excavations on Hydrogeochemical Characteristics of Kuvars Spring Water, Maltepe, Istanbul, Turkey
}

\author{
Rustem Pehlivan $^{1 *}$, Hasan Emre ${ }^{1}$, Deniz Key ${ }^{2}$ \\ ${ }^{1}$ Department of Geological Engineering, Istanbul University, Istanbul, Turkey \\ ${ }^{2}$ Yeldegirmeni Sokak, Belgin Apt. Kadikoy, Istanbul, Turkey \\ Email: pehlivan@istanbul.edu.tr
}

Received March 8, 2012; revised March 31, 2012; accepted April 29, 2012

\begin{abstract}
Spring waters consumed for drinking purposes should be clean and quality. These waters with balanced mineral distribution, which do not contain organic substances, whose physical and chemical caharacteristics comply with certain quality parameters and which do not negatively affect human health are identified as healthy water. Kuvars water is a spring water which is pumped out from the draw well at the Camurluk stream basin of Maltepe province of Istanbul and filled into bottles. The Camurluk stream basin is approximately $4.5 \mathrm{~km}^{2}$. The Camurluk stream basin is sedimentary rocks and talus deposit outcrops. Reaching of trace elements, which is found more in the talus deposit samples than outcropping quartzarenite at the basin, to underground aquifer as ions under effect of rains, water rock interaction, leakage and filtration, is prevented by illite type clay levels existing within the talus deposit stack, which have upto 20 $\mathrm{cm}$ thickness. However, negative effects of the excavation that were made at the talus deposit reflect on the hydrologic cycle and chemical compositions of well waters. This effect was at first negatively affected the physical characteristics of the well waters. During the rainy periods, the water in the excavated area which was enriched with respect to the suspended sediments was percolated into the groundwaters from the joints and cracks of the quartzarenite. The turbidity value measured in the well waters of K2 and K3 were determined as 40.3 NTU and 34.2 NTU respectively. Although at the basin, the aquifer of underground water and the well waters being managed are quartzarenite, the fact that water types belonging to well waters differ (they are not same) according to the Piper diagram and when the heavy metal content of the water of well numbered KS1 is taken as basis, that some heavy metals such as $\mathrm{Al}^{3+}, \mathrm{Fe}^{2+}, \mathrm{Ni}^{2+}, \mathrm{Mn}^{2+}$ and $\mathrm{Cu}^{2+}$ be enriched 3 to 40 times in KS2 and KS3 well waters, are caused by talus deposit-water interaction at the excavation area. After a rainfall, in the water that became turbid with the water-talus deposit interaction at the excavation area, the water-mineral interaction has caused the limit value for drinking water suggested by World Health Organization (WHO) to be exceeded with the $\mathrm{Al}^{3+}$ concentration of $189 \mathrm{ppb}$ detected in $\mathrm{KS} 2$ well water and $\mathrm{Fe}^{2+}$ concentration of $185 \mathrm{ppb}$ has caused to approach the drinking water limit value of $200 \mathrm{ppb}$ permitted by World Health Organization (WHO), United States Environmental Protection Agency (EPA), European Union (EU) and Turkish Standards (TS). Therefore, at the water basins where bottled spring waters consumed for drinking purposes are produced, technical undertakings that shall disturb the stability of geological units should not be permitted.
\end{abstract}

Keywords: Hydrogeochemistry; Kuvars Water; Talus Deposit; Excavation; Water Guality; Turkiye

\section{Introduction}

Chemical compositions of waters are determined by waterrock interactions, types of suspended sediments carried by surface waters, mineralogical and geochemical properties of bed sediments and the natural environments and environmental factors. Precipitation runoff, leakage of surface waters into rocks, climate, erosion and weathering states of geological units also contribute to this effect [1-3].

${ }^{*}$ Corresponding author.
As it is known, the element enrichment in the geochemical environment and the geochemical processes develops chemical mobilities of the elements. Various processes such as the movement of minerals, changes in mineral ions, redox potential and resedimentation affect the chemical mobility $[4,5]$.

Heavy metals that can be contained in the spring waters pass into the surface and groundwaters as a result of the natural and/or anthropogenic activities. The geological weathering and erosion can be given as examples of the natural sources and the industrial, mining and agricultural 
activities as the examples of the anthropogenic activities. Movement and resedimentation following physical and chemical weathering are activated by hydrological processes [6].

Within several countries throughout the world, some researches related to the chemistry, water-rock interaction and water qualities of bottled spring and mineral waters, which are consumed for drinking purposes, were conducted. Some of them are, one conducted by [7] about amounts of trace elements in the bottled waters of Nigeria, one by [8] about drinking waters of Ethiopia and health, A study on the geochemistry of the Han River basin and on the factors controlling the compositions of the major ions in the stream waters was conducted by [9] in China and a study on the evaluation of the natural and anthropogenic effects on the sediment geochemistry of Nestos River was conducted by [10] in Greece.

On the other hand in Turkey, limited number of studies aimed at determination of qualities of bottled waters consumed for drinking purposes and at protection of consumers were made. First of these studies was made by [11] and with this study, drinkabilities and qualities of spring and mineral waters at Istanbul, Sakarya, Bursa and Canakkale were determined. Hydrogeochemical properties and effects on human health of Kirkgecit and Ozancik hot mineral waters were evaluated by [12] and label informations of 103 brands of bottled waters being consumed throughout Turkey were evaluated again by [13] and it was determined that the amounts of ions such as $\mathrm{Fe}^{2+}, \mathrm{Zn}^{2+}, \mathrm{As}^{3+}$ and $\mathrm{Al}^{3+}$ in some spring and mineral waters were above the limit values of World Health Organization, United States Environmental Protection Agency, European Union and Turkish Standards.

In order to determine the suitability for consumption of spring and drinking waters being sold at the supermarkets in Istanbul, analysis of major ion and of several anionic components were made by [14]. With this study, it was determined that $\mathrm{As}^{3+}$ content in one of the water samples had exceeded three times the limit value of European Union (EU). High levels of arsenic in waters should be due to geological or environmental reasons.

As a result of the research on hydrogeochemistry in the Buyukmelen River basin conducted by [15], it was determined in soil samples produced by physical weathering of agglomerate, basalt, andesite, volcanic sandstone and graywacke, which are the sources of ions such as $\mathrm{Fe}^{2+}, \mathrm{Al}^{3+}$ and $\mathrm{Mn}^{2+}$, that the water-rock interaction is more effective during the rainy periods.

In the literature, there are publications about the permeability of exposed taluses in the water basins at the high altitude areas and setting forth that some geological units retains water in high proportions due to the effect of the taluses and that they serve as natural water reservoirs. In the research made by [16], it was determined that, in the watershed at the western part of the Canadian Rockies, the mountain snowpacks flows to the lowlands through the bedrocks and talus in the form of surface runoff together with melting of the snows. The drainage under the bedrock and talus interaction is deposited in the soil beneath the geological coverage on which grassland meadow has grown. It was determined that, the formation controlled by bedrock topography, had the characteristics of a water reservoir (dam).

The talus deposits in Istanbul, which are the subject matters of the present study, have the characteristics of an impermeable unit due to their geological, vegetation cover and ground properties. Since exposed taluses in the research field are over the quartzarenites, pollution of the groundwaters within the quartzarenites due to agricultural and anthropogenic effects is not possible.

In Turkey, the waters collecting within rocks and aquifers and exit to earth by themselves or taken out by technical methods from one or more outlets are defined as spring water. The spring waters in question must carry the physical and chemical characteristics specified in the Regulation Concerning Water Intended for Human Consumption [17]. Spring waters are offered for consumption for drinking purposes after they are bottled.

One important water basin at which quality spring waters consumed at Istanbul are produced is the Camurluk stream basin. That's why, this study was conducted to determine possible effects of earth excavation at outcropping talus deposit of the Camurluk stream basin on the well waters of the basin, using geologic, hydrologic and hydrogeochemical methods. Kuvars water, a spring water, is being managed at the Camurluk stream basin. The Camurluk stream basin is located at Maltepe district of Istanbul province (Figure 1). Elevation of upstream side of the Camurluk stream is approximately $395 \mathrm{~m}$ and of downstream side is about $180 \mathrm{~m}$. The Camurluk stream water basin is approximately $4.5 \mathrm{~km}^{2}$.

\section{Materials and Methods}

In order to reveal the effect of the excavation made in the talus on the chemical composition of the groundwaters, first of all, 1/10000 scaled geological map of the Camurluk stream basin was prepared. Rock samples collected from Aydos Formation. Soil samples were taken from the talus in the research field by soil auger as approximately $1 \mathrm{~kg}$ each. On the other hand, the water wells were sampled in the arid (September 2009) and rainy (December 2010) periods.

Mineral constituents of the rock samples in the study area were examined by optical microscopy. The mineralogical identification of rock and talus deposit samples were done using X-ray diffractometry (XRD, Phillips 1730 diffractometer with a $\mathrm{CuK} \alpha$ source) at the Geochemistry Laboratory, Istanbul University. 


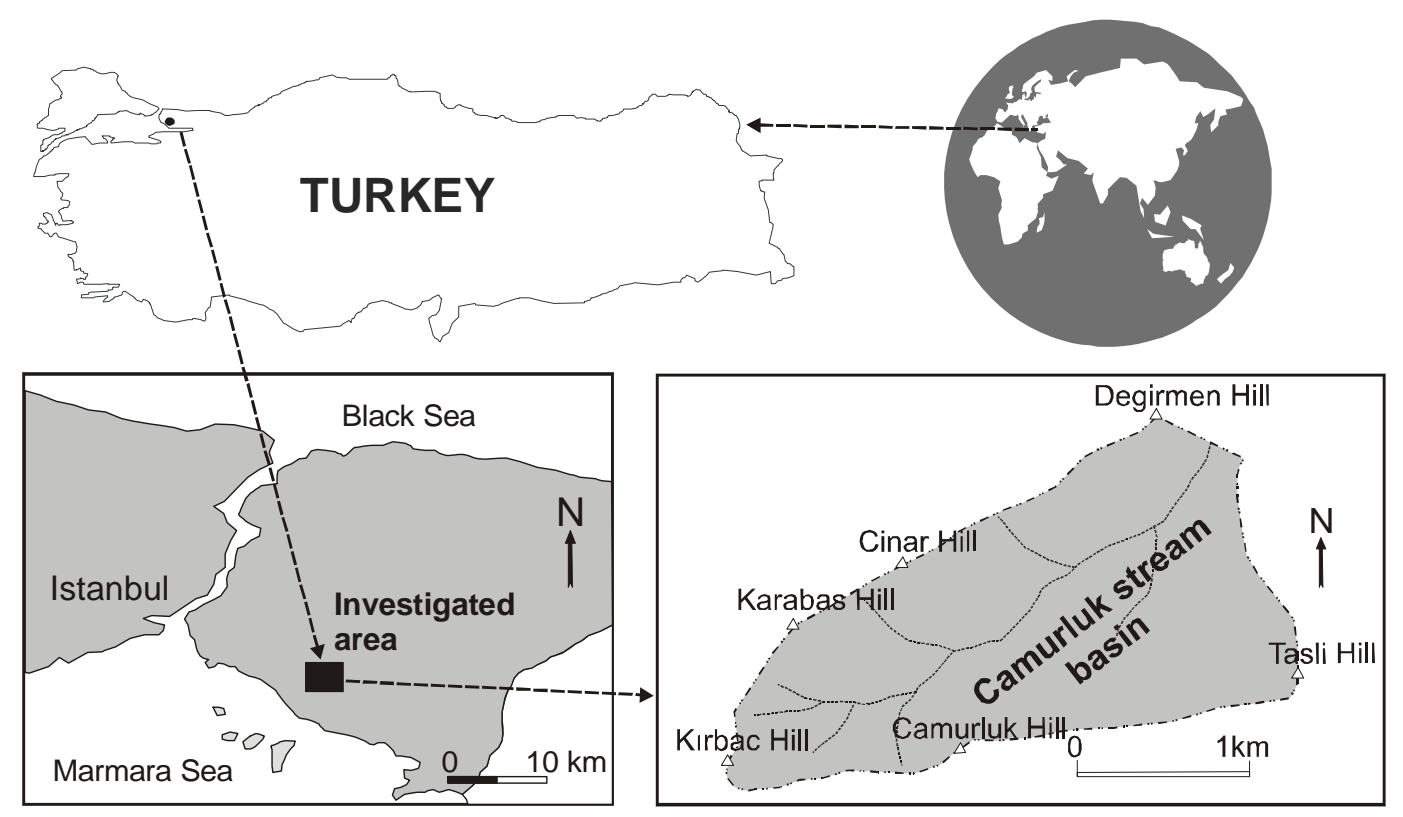

Figure 1. Location map of the study area.

The major compounds $\left(\mathrm{SiO}_{2}, \mathrm{Al}_{2} \mathrm{O}_{3}, \mathrm{Fe}_{2} \mathrm{O}_{3}, \mathrm{MgO}\right.$, $\left.\mathrm{MnO}, \mathrm{CaO}, \mathrm{TiO}_{2}, \mathrm{Na}_{2} \mathrm{O}, \mathrm{K}_{2} \mathrm{O}, \mathrm{P}_{2} \mathrm{O}_{5}, \mathrm{LOI}\right)$ and trace element ( $\mathrm{Fe}, \mathrm{Al}, \mathrm{As}, \mathrm{Hg}, \mathrm{Ag}, \mathrm{Co}, \mathrm{Cr}, \mathrm{Cd}, \mathrm{Pb}, \mathrm{Ni}, \mathrm{Ti}, \mathrm{Ba}$, $\mathrm{Mn}, \mathrm{Zn}, \mathrm{Cu}, \mathrm{Se}, \mathrm{Sb}, \mathrm{U}$ ) analyses of rock and talus deposit samples were performed at Alschemex Laboratories, Canada. The trace element studies were carried out using the ICP-MS (Inductively Coupled Plasma-Mass Spectrometer) technique in the laboratory. The concentration of major oxides were analyzed by lithium borate fusion and XRF.

Well water samples were collected in two sets of 1000 $\mathrm{ml}$ polyethylene bottles, one acidified with $\mathrm{HNO}_{3}$ for cation analysis and the other untreated for anions. The major ion and tubidity analyses of the well waters were performed at the Advanced Analysis Laboratory of Istanbul University. $\mathrm{Na}^{+}, \mathrm{K}^{+}, \mathrm{Ca}^{2+}$ and $\mathrm{Mg}^{2+}$ were analysed by atomic absorption spectrophotometry (AAS), with a precision of $\pm 5 \%$. $\mathrm{Cl}^{-}$and $\mathrm{HCO}_{3}^{-}$were determined by colorimetric method. $\mathrm{SO}_{4}^{2-}$ was analysed by turbidimetric method. Overall charge balance errors ranged between $4.61 \%$ and $4.76 \%$. The balance errors (\%) were accurated. Turbidity was analysed by nephelometric method.

Heavy metal analyses $\mathrm{Al}^{3+}, \mathrm{As}^{3+}, \mathrm{Ag}^{3+}, \mathrm{Hg}^{2+}, \mathrm{Co}^{2+}$, $\mathrm{Cd}^{2+}, \mathrm{Cr}^{3+}, \mathrm{Pb}^{2+}, \mathrm{Ni}^{2+}, \mathrm{Ti}^{4+}, \mathrm{Se}^{4+}, \mathrm{Si}^{4+}, \mathrm{Ba}^{2+}, \mathrm{Mn}^{2+}, \mathrm{Zn}^{2+}$, $\mathrm{Cu}^{2+}, \mathrm{Sb}^{3+}, \mathrm{U}^{3+}$ and $\mathrm{Fe}^{2+}$ ) of the well waters were carried out using inductively coupled plasma mass spectrometry (ICP-MS) at a detection limit of $0.01 \mathrm{ppb}$.

The $\mathrm{pH}$ and electrical conductivity were measured in the field using portable Hanna EC and pH meters. Before measurements, the apparatus was calibrated with freshly prepared buffer solutions of $\mathrm{pH} 4.0$ and 7.00. The total dissolved solids (TDS) were calculated as the sum of the above ion concentrations.

\section{Climate}

At the research area, summers are cool but not rainy. Winters are cold and snowy. The period with the highest precipitation is winter. Taking also into consideration the elevation of $395 \mathrm{~m}$ of the basin including the water well belonging to Kuvars water, it can be said that main feeding source of the underground water at the Camurluk stream basin is precipitation.

\section{Evapotranspiration}

The conversion of water from liquid or solid state to water vapor is called "evaporation", release of the water within a plant as vapor to the atmosphere is called "transpiretion". The sum of these two events is called "evapotranspiration".

The amount of water released to the atmosphere by ground and vegetation cover fed by precipitation and groundwaters is called the potential evapotranspiration (Etp). The precipitation and ground may not always meet the water required by potential evapotranspiration. In this case, the amount of water that can be provided by ground, vegetation cover and precipitation to "evapotranspiration" is called the real evapotranspiration (Etr).

According to [18] method, the water balance table of a place is prepared by using average monthly temperature, average monthly precipitation and monthly evapotranspiration values of that place. The table of water balance obtained with these data shows the annual amount of water stored in the soil, monthly change of the water stored, annual real evapotranspiration amounts, water surplus and deficit in the soil, runoff and moisture content.

In the Thornthwaite method, the formula Etp $=16 \times$ $(10 \mathrm{xt} / \mathrm{I})^{\mathrm{a}} \mathrm{x} \mathrm{p}$ is used in calculating the potential evapo- 
transpiration values. Here,

$\mathrm{t}$ : Average monthly temperature $\left({ }^{\circ} \mathrm{C}\right)$

i: Monthly temperature index

I: Annual total heat index

$\mathrm{i}=(\mathrm{t} / 5)^{1.514} \mathrm{I}=\Sigma \mathrm{i}$

$\mathrm{a}=6.75 \times 10^{-7} \times \mathrm{I}^{3}-7.71 \times 10^{-5} \times \mathrm{I}^{2}+1.79 \times 10^{-2} \times \mathrm{I}+$ 0.492

p: Latitude correction factor, and

Etp: Monthly potential evapotranspiration amount (mm).

Utilizing the precipitation and temperature values obtained from Istanbul Directorate of Meteorology [19] covering the years 1970-2010, water budget of the Camurluk stream basin was calculated (Table 1). From the calculations made using the monthly precipitation and temperature values measured for the Camurluk stream basin, annual sum of the potential evapotranspiration (Etp) was found as $766.6 \mathrm{~mm}$ and sum of the real evapotranspiration (Etr) as $611.2 \mathrm{~mm}$. According to the Table 1, since monthly precipitation in the months January, February, March and April exceeds the real evapotranspiration, surface runoff of the surplus precipitation happens. The moisture proportion for the months May, June, July, August and September was found negative (-). Total annual sum of the water surplus is $283.8 \mathrm{~mm}$. This value is $36.5 \%$ of the total precipitation of $694.5 \mathrm{~mm}$. Water deficit in the months July, August and September is $330.5 \mathrm{~mm}$. Ground reserve of $100 \mathrm{~mm}$ has been completed in December.

\section{Geology}

With the research, firstly, in order to determine the regions where quartzarenites outcrop at the Camurluk stream basin, 1/10000 scaled geology map of an area of $4.5 \mathrm{~km}^{2}$ was prepared and geological cross section is shown in Figure 2(a). The geological sequence at the study area is as Kurtkoy Formation, Aydos Formation and Talus deposit from bottom up [20]. These are:

\subsection{Kurtkoy Formation}

Kurtkoy Formation is formed of arkose and shale. It is a medium and thick layered structure. Arkose contain quartz (average 50 vol.\%), feldspar (25\%), rock fragment $(15 \%)$ and cement $(10 \%)$ material. It is at lower Ordovisian age [20] (Figure 2).

\subsection{Aydos Formation}

Aydos Formation occur in most of the study area and consist of Consists of quartzarenite, clayed shale and clayed sandstones. The quartz arenites at the research area are corrosion resistant and quite hard. Layering of quartzarenites varies from $20 \mathrm{~cm}$ to $80 \mathrm{~cm}$. Between the quartzarenite layers, there exist reddish, yellowish clayey shale and clayey sandstone levels upto the thickness of 5 $-10 \mathrm{~cm}$.

At Aydos Formation, apparent and regular joints and cracks and lenses exhibiting quartz conglomerate characteristic exist. Secondary quartz filling has developed at the cracks. Average Istanbul-wide thickness of Aydos Formation is approximately $300 \mathrm{~m}$. Almost whole of this thickness is seen in the Camurluk stream basin. The quartzarenite observed in pinkish, whitish colours consists of plutonic quartz grains which are grown very well tall, cemented, having fine and coarse sand sizes.

Quartzarenite, consists of quartz (average 95 vol.\%), labradorite, mica, opaque minerals and rock fragments. The clayey sahale contain quartz, calcite, plagioclase and clay minerals. The clayey sandstone composed of quartz, plagioclase, muscovite and clay minerals. It was determined by X-ray powder difractogram that the soil sample contain quartz, labradorite, and illite type clay minerals. It is is at middle Ordovisian age [20] (Figure 2).

Table 1. Values of water budget calculated by the [18] method for the Camurluk stream basin.

\begin{tabular}{|c|c|c|c|c|c|c|c|c|c|c|c|c|c|}
\hline & Jan & Feb & Mar & Apr & May & Jun & Jul & Aug & Sep & Oct & Nov & Dec & Annual \\
\hline $\mathbf{T}$ & 6.1 & 6.1 & 7.9 & 12.3 & 16.9 & 21.6 & 23.9 & 23.8 & 20.1 & 15.7 & 11.4 & 8.1 & 14.5 \\
\hline TI & 1.35 & 1.35 & 2.0 & 3.91 & 6.32 & 9.17 & 10.68 & 10.62 & 8.22 & 5.65 & 3.48 & 2.08 & 64.83 \\
\hline CF & 0.84 & 0.83 & 1.03 & 1.11 & 1.24 & 1.25 & 1.27 & 1.18 & 1.04 & 0.96 & 0.83 & 0.81 & \\
\hline CPE & 12.4 & 12.3 & 20.7 & 35.5 & 74.4 & 122.5 & 152.4 & 139.2 & 95.7 & 57.7 & 26.6 & 20.25 & 766.6 \\
\hline $\mathbf{P}$ & 85.5 & 69.9 & 63.3 & 46.4 & 31.5 & 26.5 & 23.3 & 33.0 & 39.4 & 84.2 & 89.4 & 103.0 & 695.4 \\
\hline DS & 0.0 & 0.0 & 0.0 & 0.0 & -42.9 & -57.1 & 0.0 & 0.0 & 0.0 & 29.5 & 62.8 & 7.7 & \\
\hline $\mathrm{S}$ & 100 & 100 & 100 & 100 & 57.1 & 0.0 & 0.0 & 0.0 & 0.0 & 29.5 & 92.3 & 100 & \\
\hline ETR & 12.4 & 12.3 & 20.7 & 35.5 & 74.4 & 83.6 & 23.3 & 33 & 39.4 & 84.2 & 89.4 & 103 & 611.2 \\
\hline WD & 0.0 & 0.0 & 0.0 & 0.0 & 0.0 & 38.9 & 129.1 & 106.2 & 56.3 & 0.0 & 0.0 & 0.0 & 330.5 \\
\hline EW & 73.1 & 57.5 & 42.5 & 10.8 & 0.0 & 0.0 & 0.0 & 0.0 & 0.0 & 29.4 & 62.8 & 7.7 & 283.8 \\
\hline RO & 48.2 & 52.90 & 47.8 & 29.4 & 14.7 & 7.4 & 3.7 & 1.85 & 0.93 & 14.8 & 38.9 & 23.3 & 283.8 \\
\hline MR & 5.8 & 4.68 & 2.05 & 0.30 & -0.57 & -0.78 & -0.84 & -0.76 & -0.58 & 0.53 & 2.36 & 4.08 & \\
\hline
\end{tabular}

[T (Temperature- $\left.{ }^{\circ} \mathrm{C}\right)$; TI (Temperature Indice); PE (Potential Evapotranspiration-mm); CF (Correction Factor); CPE (Corrected PE-mm); P (Precipitation-mm); DS (Storage Change); S (Storage); ETR (Real Evapotranspiration-mm); WD (Water Defiency); EW (Excessive Water); RO (Runoff-mm); MR (Moisture Ratio)]. 


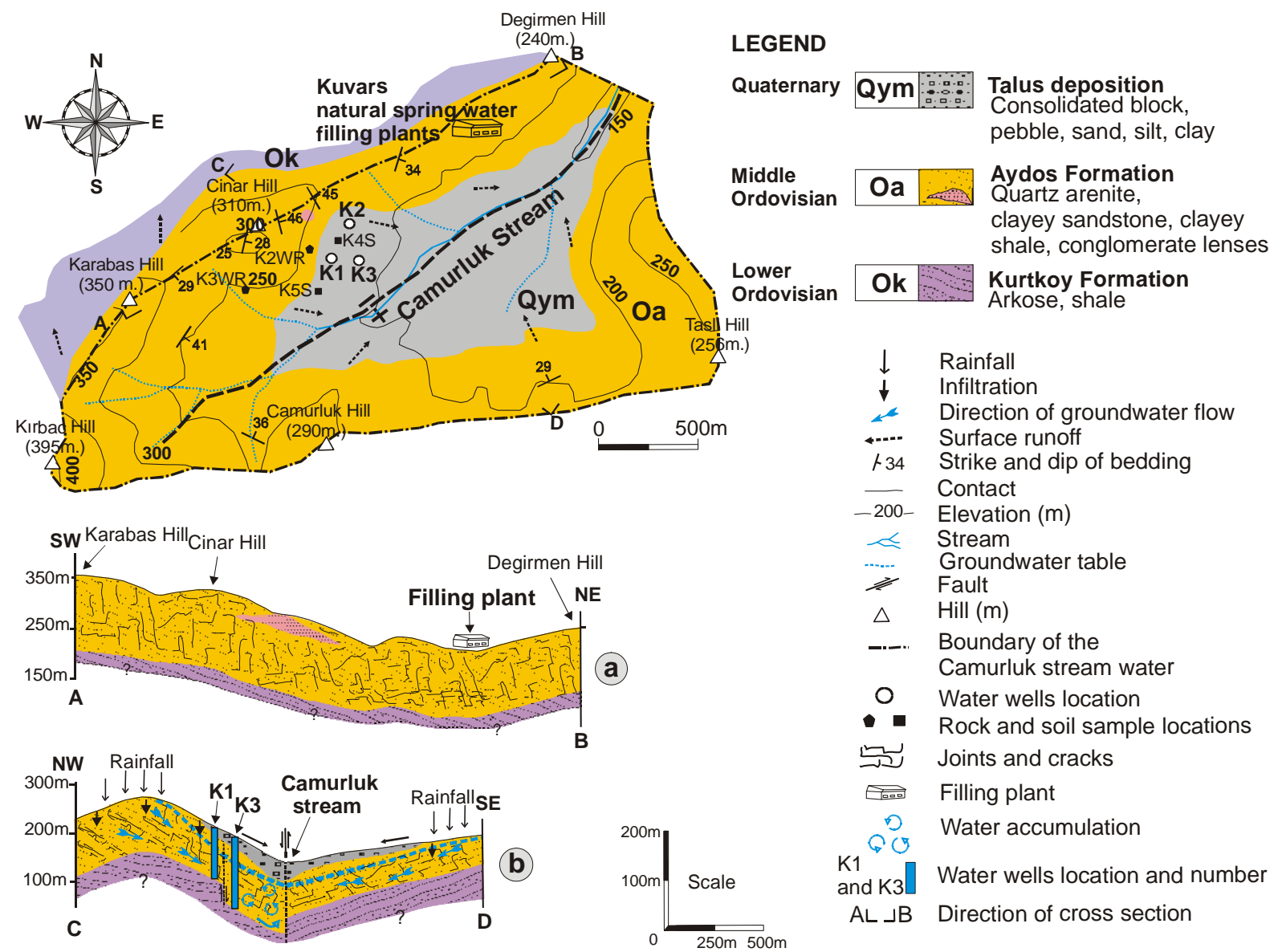

Figure 2. Schematic cross-sections and geological map of the study area, (a) Geological cross-section, (b) Hydrological cross -section.

\subsection{Talus Deposit}

At the hills of the Camurluk stream basin, there exist sharp edged quartzarenite gravels and blocks produced by physical weathering with sizes up to $50 \mathrm{~cm}$ and the average size of $2-10 \mathrm{~cm}$. Between the gravels and blocks, there exist finer grained reddish brown sandy clays.

The quartz and clay minerals are typically produced from the quartzarenite and clayey sandstones, which are the lithology of the Aydos formation. The quartz and clay minerals were differentiated during weathering. While the quartz mineral has been ionized and transported with the surface water, since the clay mineral is immobile, it has accumulated at the place of weathering. The materials produced by geological weathering such as rock fragments with different sizes, gravels, sand and silt sized materials and clay have been moved downward and stored at the lowland or low-sloped areas and formed current talus deposit [20] (Figure 2).

\subsection{Structural Geology}

The cracks and discontinuities observed at quartzarenites indicate that research area has been affected quite much by regional tectonics. A vertical fault has formed in the Camurluk stream basin due to movement in the North Anatolian Fault.

The North Anatolian Fault is one of the most important tectonic features of the North Anatolian Fault Zone system, which is an active, right lateral strike-slip fault approximately $1200 \mathrm{~km}$ long which separates the Eurasian continental plate from the Anatolian sub-plate [15].

\section{Hydrogeology}

Since the debits of the spring waters are not sufficient at the densely populated cities of Turkey, firstly it was permitted to produce spring water from the boreholes with $10-20 \mathrm{~m}$ depth. Since it still could not solve the problem, it was allowed to operate the groundwaters to be pumped out from the water wells as spring water pursuant to a regulation issued by the Ministry of Health in 2005. That's why these waters are sold as spring or mineral waters in Turkey.

The vegetal ground cover at the top level of (Figure 3(a)) outcropping talus deposit among K1 water well, which is operated under Kuvars water brand, K2 water 


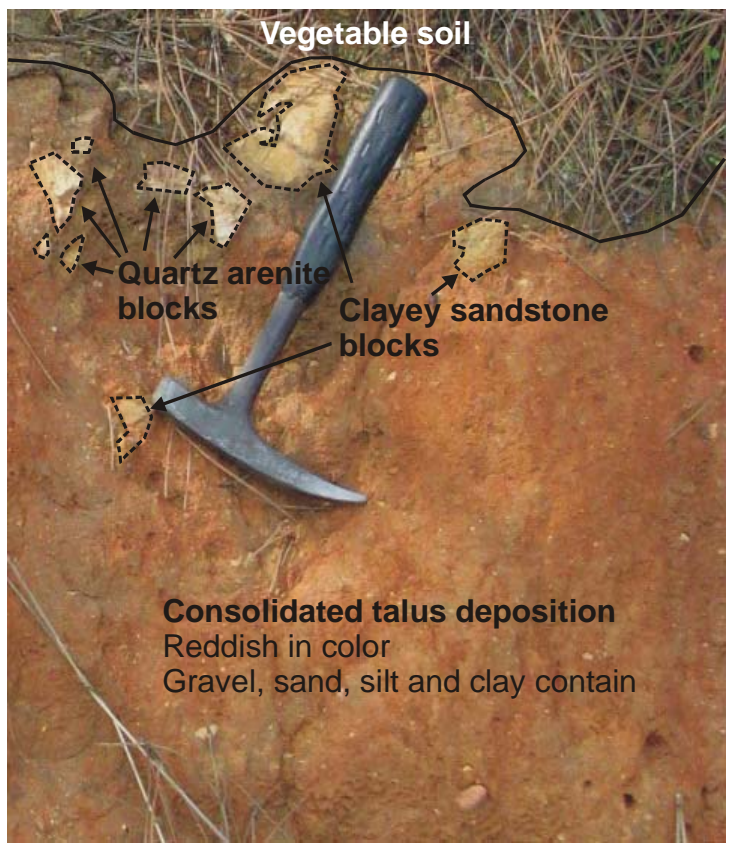

Figure 3. A block diagram representation of the talus deposition, water wells and hydrological cycle. a) Pre-excavation view of talus deposits in the study area; b) K2 and K3 numbered wells affected by underground waters infiltration of suspended sediment in the rainy period from the excavation area; c) Detailed column section of the talus deposition.

well, which will be taken into operation at a near future and $\mathrm{K} 3$ water well owned by Kocaturk, were excavated by earth movers (Figure 3(b) and Figure 4). The purpose of excavation was construction.
The spring waters drawn from K1, K2 and K3 water wells by submersible pump are waters accumulated in the crack and discontinuity zones in quartzarenites.

Camurluk steram basin is the highest altitude among the surroundings basins. For this reason, no groundwater input from the surroundings basins into the Camurluk stream basin. At the Camurluk stream basin, level of the groundwater may decrease even partially, due to, for example, lower rainfall caused by aridity and/or pumping out excessive water (illegally) from the water wells.

Since the clayed levels within the talus deposit which are rich in illite minerals are consolidated, it prevents water entry into the aquifer below the talus deposit from surface likely to occur as leakage/filtration by effect of rain (Figure 3(c)).

With the unpermitted excavation made on an area of appximately $1500 \mathrm{~m}^{2}$ in between the water wells, hundreds $\mathrm{m}^{3}$ of soil was excavated (Figure 4). First negative influences of the mentioned intervention (Figure 3(b)) were seen after the first rain fell to the region. After the rain fell on the soil that was loosened and rich in clay minerals, the surface water has become turbid.

\section{Water Balance}

Monthly variation graph for the precipitation and potential evaporation is given in the Figure 5. According to the Figure 5, perticipation was accepted as the feeding source in determining the available groundwater potential of the Camurluk stream basin. According to the measurements for 40 years obtained from Istanbul Meteorology

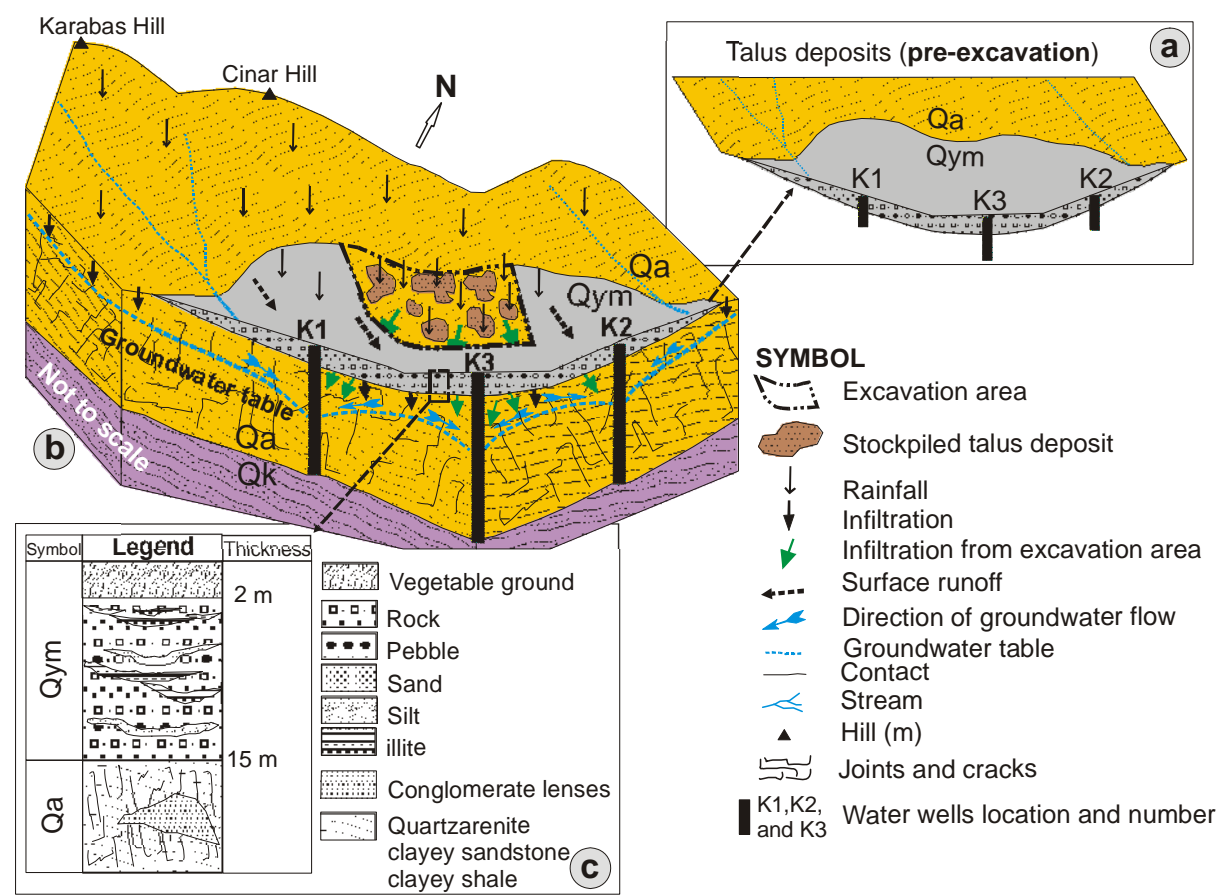

Figure 4. Positions of the K1, K2 and K3 numbered wells in the excavation area. 


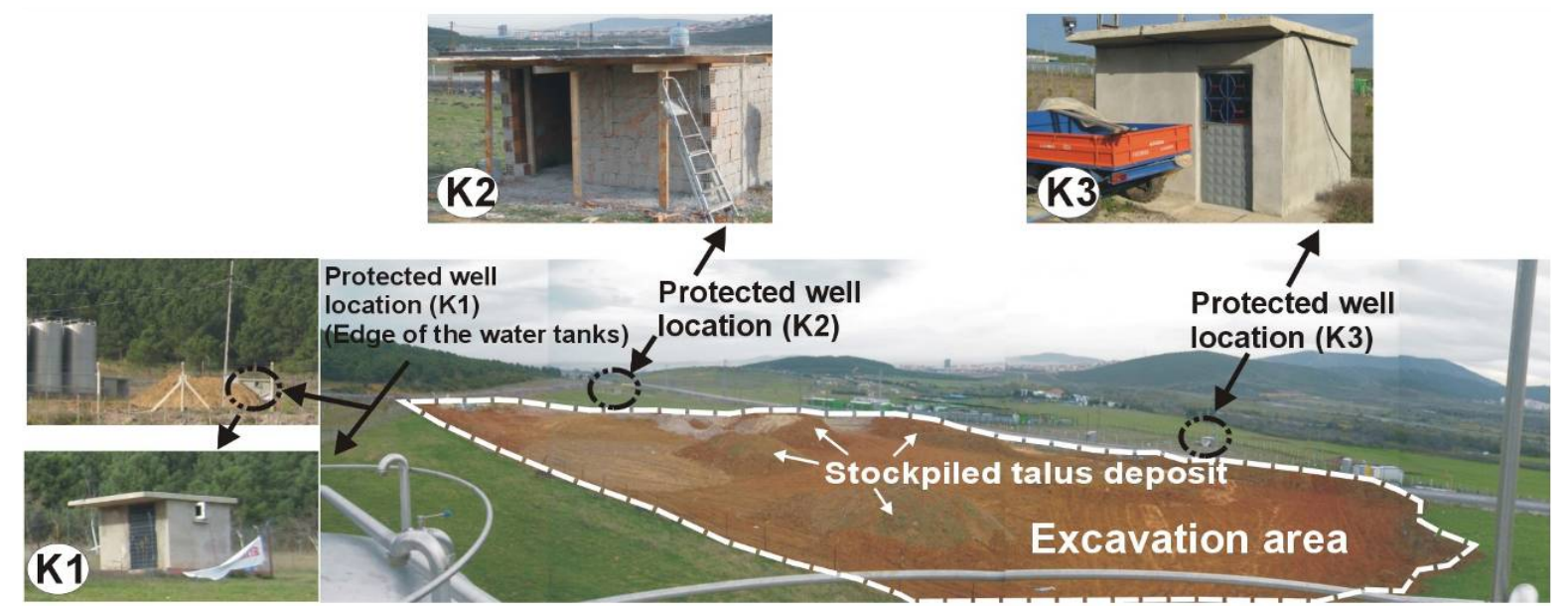

Figure 5. Thornthwaite's water budget diagram in the Camurluk stream basin.

Station, the mean amount of rainfall for the study area and around was determined as $694.5 \mathrm{~mm}$.

Considering the recharge (feeding) region of 3.562 $\mathrm{km}^{2}$, the amount of rainfall to the recharge region was calculated as $2.472 \times 10^{6} \mathrm{~m}^{3} /$ year. The flow direction of the groundwaters is from higher altitude levels to the lower altitude levels (in the flow direction of the Camurluk stream). Since the real evaporation (Etr) in the study area was calculated as $611.2 \mathrm{~mm}$ using the Thornthwaite method, the rainfall for the recharge region is $2.177 \times 10^{6}$ $\mathrm{m}^{3} /$ year. In case the discharge and recharge amounts are assumed equal for the recharge region, the difference between the recharge and discharge amounts is found as $0.2949 \times 10^{6} \mathrm{~m}^{3} /$ year. Considering that the amount of water that can be used reliably corresponds to $70 \%$ of $0.2949 \times 10^{6} \mathrm{~m}^{3} /$ year, the amount of underground water that can be used reliably for the Camurluk stream basin was calculated as $206400 \mathrm{~m}^{3} /$ year $\left(0.2064 \times 10^{6} \mathrm{~m}^{3} /\right.$ year).

\section{Geochemistry}

The results of major oxides and trace element analysis of the rock and talus deposit samples taken from the Camurluk stream basin are presented in Table 2. According to the analysis results, quartzarenite samples contain more than $96 \% \mathrm{SiO}_{2}$. At the soil samples, amounts of $\mathrm{Al}_{2} \mathrm{O}_{3}$ and $\mathrm{Fe}_{2} \mathrm{O}_{3}$ are more than that of quartzarenite. When the contents of trace elements in rock and talus deposit samples are compared, it was determined that the amounts of trace elements in talus deposit samples were more than that of quartzarenite.

Since the quartzarenites settle at high energy shallow and clean coastal environments, the geochemistry of the minerals in the rock to low trace element amounts within rock. On the other hand, high proportion of trace elements in soil samples is caused by element enrichment developing after weathering of quartzarenite.
Table 2. Major element (\%) and trace element analysis results (ppm) in rock (WR) and talus deposit (S) samples.

\begin{tabular}{|c|c|c|c|c|}
\hline & $\begin{array}{c}\text { K2WR } \\
\text { (Quartzarenite) }\end{array}$ & $\begin{array}{c}\text { K3WR } \\
\text { (Quartzarenite) }\end{array}$ & $\begin{array}{l}\text { K4S } \\
\text { (Soil) }\end{array}$ & $\begin{array}{l}\text { K5S } \\
\text { (Soil) }\end{array}$ \\
\hline $\mathrm{SiO}_{2}$ & 97.45 & 96.59 & 78.84 & 72.81 \\
\hline $\mathbf{A l}_{2} \mathbf{O}_{3}$ & 0.88 & 0.88 & 7.19 & 11.44 \\
\hline $\mathrm{Fe}_{2} \mathrm{O}_{3}$ & 0.73 & 1.39 & 4.91 & 5.74 \\
\hline MnO & 0.01 & 0.01 & 0.12 & 0.07 \\
\hline MgO & 0.09 & 0.08 & 0.34 & 0.57 \\
\hline $\mathrm{CaO}$ & 0.03 & 0.03 & 0.16 & 0.21 \\
\hline $\mathrm{Na}_{2} \mathrm{O}$ & 0.11 & 0.11 & 0.26 & 0.37 \\
\hline $\mathbf{K}_{2} \mathbf{O}$ & 0.22 & 0.15 & 0.77 & 1.17 \\
\hline $\mathrm{TiO}_{2}$ & 0.04 & 0.23 & 0.84 & 0.87 \\
\hline $\mathbf{P}_{2} \mathbf{O}_{5}$ & 0.02 & 0.03 & 0.08 & 0.08 \\
\hline LOI & 0.23 & 0.35 & 6.28 & 6.68 \\
\hline Total & 99.81 & 99.85 & 99.79 & 100.01 \\
\hline Al & 0.45 & 0.44 & 3.46 & 5.74 \\
\hline Sb & 0.18 & 0.47 & 1.61 & 1.05 \\
\hline As & 1.3 & 2.5 & 12.6 & 13.5 \\
\hline Ba & 90 & 20 & 230 & 310 \\
\hline Cd & $<0.02$ & $<0.02$ & 0.09 & 0.03 \\
\hline $\mathrm{Cr}$ & 18 & 33 & 112 & 89 \\
\hline Co & 0.6 & 0.4 & 18.3 & 21 \\
\hline $\mathbf{C u}$ & 3.2 & 2.6 & 14 & 17.1 \\
\hline $\mathbf{F e}$ & 4000 & 9200 & 31,100 & 36,900 \\
\hline $\mathbf{T i}$ & 190 & 880 & 4030 & 4190 \\
\hline Mn & 39 & 31 & 889 & 541 \\
\hline $\mathbf{P b}$ & 2.1 & 2.2 & 27.5 & 22.3 \\
\hline Hg & $<0.01$ & $<0.01$ & 0.03 & 0.10 \\
\hline $\mathbf{N i}$ & 2 & 2.5 & 24.3 & 34.8 \\
\hline Se & 1 & 1 & 2 & 2 \\
\hline Ag & 0.03 & 0.06 & 0.11 & 0.09 \\
\hline $\mathbf{U}$ & 0.3 & 0.3 & 2.4 & 2.4 \\
\hline Zn & 2 & 4 & 36 & 46 \\
\hline
\end{tabular}




\section{Hydrogeochemistry}

Chemical compositipns of surface and underground waters change following interaction with geological units and physical and chemical weatherings at the surrounding rocks. This change may be realized as passing of the ions mobilized from the rocks, minerals and soils and suspended sediments into the spring waters. The elements such as $\mathrm{Al}^{3+}, \mathrm{Fe}^{2+}$ and $\mathrm{Mn}^{2+}$ within the clay minerals, which are suspended sediments, may pass into the surface and underground waters as ions (heavy metal) following water-mineral interaction [21]. Hence, concentrations in natural waters of some ions that may negatively affect human health may increase [22,23].

\subsection{Some Technical Properties of Water Wells}

Water well $\mathrm{K} 1$ has a $100 \mathrm{~m}$ depth, water well $\mathrm{K} 2$ has a $128 \mathrm{~m}$ depth and water well K3 has a $150 \mathrm{~m}$ depth. The cracks and joints in the quartzarenites having water input to the wells were installed filter pipes. Those parts with no well input (talus, the levels of quartzarenite not containing cracks or joints and arkoses) was installed plain pipes (Figure 6).

Since at first $1-2 \mathrm{~m}$ of the wells, vegetal soil and next talus deposit have been cut, plain pipes have been installed at $10 \mathrm{~m}$ top part of well $\mathrm{K} 1$, at $12 \mathrm{~m}$ top part of the well $\mathrm{K} 2$ and $15 \mathrm{~m}$ top part at the well $\mathrm{K} 3$, from well top downwards.

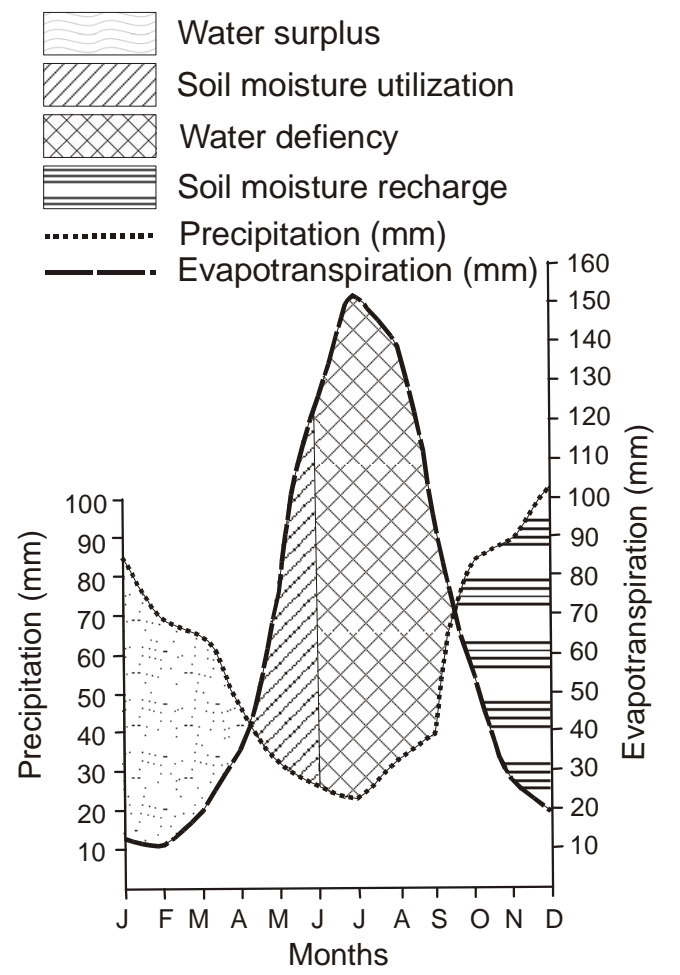

Figure 6. Geological logs and pipe types of water wells in the Camurluk stream basin.
Daily $20 \mathrm{~m}^{3}$ of water is drawn from well $\mathrm{K} 1,10 \mathrm{~m}^{3}$ from well $\mathrm{K} 2$ and $40 \mathrm{~m}^{3}$ from well $\mathrm{K} 3$. Next to the well $\mathrm{K} 1$, since the well is being operated now, there are 10 silo type tanks in which the water drawn is stored to be used when needed.

\subsection{Major Ion Content of Well Waters}

The results of major ion analysis of the spring waters taken from $\mathrm{K} 1, \mathrm{~K} 2$ and $\mathrm{K} 3$ water wells at the stream basin in summer 2010, winter 2010 and 2011 are given in Table 3. According to analysis results, with respect to major ion contents of spring waters, the amount of ions is the most in KS2 well water $(109 \mathrm{mg} / \mathrm{l}$ in Winter 2011) and is the least in KS1 well water $(41.21 \mathrm{mg} / \mathrm{l}$ in Summer 2010).

\subsection{Water-Rock Interaction}

The composition of the well waters for including $\mathrm{pH}, \mathrm{EC}$, Turbidity and TDS are given in Table 3. In the well waters, $\mathrm{pH}$ values ranges from 6.0 to 6.6 . The $\mathrm{pH}$ of the well water samples are near-neutral to slightly acidic. The EC in the well waters ranges from 64.5 to $112 \mu \mathrm{S} /$ $\mathrm{cm}$. The total dissolved solids (TDS) ranges from 41.21 to $109 \mathrm{mg} / \mathrm{l}$. The NICB of the well waters ranges from 14.17 to 28.65 .

In natural waters, the measured major elements $\left(\mathrm{K}^{+}\right.$, $\mathrm{Na}^{+}, \mathrm{Ca}^{2+}, \mathrm{Mg}^{2+}, \mathrm{Cl}^{-}, \mathrm{HCO}_{3}^{-}$and $\mathrm{SO}_{4}^{2-}$ ) account for most of the dissolved load, and the Normalized In Organic Charge Balance $(\mathrm{NICB})=\left[\left(\mathrm{TZ}^{+}-\mathrm{TZ}\right) / \mathrm{TZ}^{+}\right.$in meq/l] x $100 \%$ where $\mathrm{TZ}^{+}=\mathrm{Na}^{+}+\mathrm{K}^{+}+2 \mathrm{Mg}^{2+}+2 \mathrm{Ca}^{2+}$ and $\mathrm{TZ}^{-}=\mathrm{Cl}^{-}+\mathrm{HCO}_{3}^{-}+2 \mathrm{SO}_{4}^{2-}$ ) is used to estimate overall analytical uncertainty (Table 3). NICB should ideally be close to zero, unless one or more ions have been overlooked in the analyses. This is far in excess of the analytical error and suggests the existence of unanalyzed anions. [24] reported that pulses of $\mathrm{Ca}^{2+}$ associated with unmeasured anions (e.g., nitrate, phosphate, organic) from anthropogenic sources (e.g., fertilizer) must be responsible for the high NICB in well water samples.

Quartzarenite and sandstone blocks, gravels, sand and illite type sediments which are dominantly observed in the talus deposit sometimes exhibits horizontal and vertical sorting in the storage environment. Talus deposits contain lens-shaped clay levels. Clay sand and graveled levels of talus deposits have been well-consolidated (Figure 7).

According to logs belonging to $\mathrm{K} 1, \mathrm{~K} 2$ and $\mathrm{K} 3$ numbered water wells in the study area, thickness of talus deposit is about $15 \mathrm{~m}$ at the region where water wells are located. Thickhness of talus deposit increases hillside down in the direction of slope and reaches $30 \mathrm{~m}$ in the Camurluk stream.

The position of the well waters in the Schoeller [25], Piper [26] and Gibbs [2] diagrams are shown Figure 8-10. Figure 8 shows the following proportions of anions 
Table 3. The results of major ion analysis of the KS1, KS2 and KS3 numbered well water samples in summer 2009 and winter 2010.

\begin{tabular}{|c|c|c|c|c|c|c|c|c|c|c|c|c|}
\hline \multirow{3}{*}{$\begin{array}{l}\text { Well no } \\
\text { Sample no } \\
\text { Ions }\end{array}$} & \multicolumn{3}{|c|}{ K1 } & \multicolumn{3}{|c|}{ K1 } & \multicolumn{3}{|c|}{$\mathrm{K} 2$} & \multicolumn{3}{|c|}{$\mathrm{K} 3$} \\
\hline & \multicolumn{3}{|c|}{ KS1 Summer (2009) } & \multicolumn{3}{|c|}{ KS1 Winter (2010) } & \multicolumn{3}{|c|}{ KS2 Winter (2010) } & \multicolumn{3}{|c|}{ KS3 Winter (2010) } \\
\hline & $\mathrm{mg} / 1$ & meq/1 & meq/1 (\%) & $\mathrm{mg} / \mathrm{l}$ & meq/1 & meq/1(\%) & $\mathrm{mg} / 1$ & meq/1 & meq/1 $(\%)$ & $\mathrm{mg} / 1$ & $\mathrm{meq} / 1$ & meq/1 (\%) \\
\hline $\mathrm{pH}$ & 6.0 & & & 6.2 & & & 6.6 & & & 6.3 & & \\
\hline $\mathrm{Na}^{+}$ & 6.8 & 0.2957 & 48.23 & 8.2 & 0.3566 & 45.13 & 9.2 & 0.4001 & 26.71 & 8.0 & 0.3479 & 50.71 \\
\hline $\mathrm{K}^{+}$ & 1.9 & 0.0486 & 7.29 & 1.8 & 0.0460 & 5.82 & 1.4 & 0.0358 & 2.39 & 1.6 & 0.0409 & 5.96 \\
\hline $\mathrm{Ca}^{2+}$ & 3.57 & 0.1750 & 28.54 & 5.1 & 0.2500 & 31.64 & 18.5 & 0.9068 & 60.55 & 3.56 & 0.1754 & 25.56 \\
\hline $\mathrm{Mg}^{2+}$ & 1.14 & 0.0938 & 15.29 & 1.67 & 0.1374 & 17.39 & 1.90 & 0.1547 & 10.33 & 1.48 & 0.1218 & 17.75 \\
\hline $\mathrm{Cl}^{-}$ & 5.2 & 0.1464 & 26.18 & 4.4 & 0.1239 & 17.25 & 5.1 & 0.1436 & 10.22 & 3.1 & 0.0873 & 13.01 \\
\hline $\mathrm{SO}_{4}^{2-}$ & 9.5 & 0.1979 & 34.40 & 12.0 & 0.2500 & 34.81 & 14.9 & 0.3104 & 22.09 & 8.1 & 0.1687 & 25.15 \\
\hline $\mathrm{HCO}_{3}^{-}$ & 13.1 & 0.2147 & 38.40 & 21 & 0.3442 & 49.93 & 58 & 0.9508 & 67.68 & 25.3 & 0.4147 & 61.83 \\
\hline TDS & 41.21 & & & 54.17 & & & 109 & & & 51.14 & & \\
\hline $\mathrm{EC}(\mu \mathrm{S} / \mathrm{cm})$ & 81 & & & 107 & & & 112 & & & 64.5 & & \\
\hline Turbidity (NTU) & 0.0 & & 0.0 & & & & 40.3 & & & 34.2 & & \\
\hline$\Sigma$ cations & & 0.6131 & & & 0.7900 & & & 1.4974 & & & 0.6860 & \\
\hline$\Sigma$ anions & & 0.5590 & & & 0.7181 & & & 1.4048 & & & 0.6707 & \\
\hline $\mathrm{TZ}^{+}$ & & 0.8819 & & & 1.1774 & & & 2.4042 & & & 0.9832 & \\
\hline $\mathrm{TZ}^{-}$ & & 0.7569 & & & 0.9681 & & & 1.7152 & & & 0.8394 & \\
\hline${ }^{\mathrm{b}}$ Check acc. & & -4.61 & & & 4.76 & & & -3.19 & & & 1.12 & \\
\hline${ }^{\mathrm{c}} \mathrm{NICB}$ & & 14.17 & & & 17.77 & & & 28.65 & & & 14.62 & \\
\hline
\end{tabular}

${ }^{\mathbf{b}}$ Check accuracy $(\%$ balance error $)=\left[\left(\sum\right.\right.$ cations $-\sum$ anions $) /\left(\sum\right.$ cations $+\sum$ anions $\left.)\right] \times 100$;

${ }^{\mathrm{c}}$ Normalized Inorganic ChargeBalance $(\% \mathrm{NICB})=\left[\left(\mathrm{TZ}^{+}-\mathrm{TZ}^{-}\right) / \mathrm{TZ}+\right] \times 100 \%(\mathrm{meq} / 1) \cdot \mathrm{TZ}^{+}=\mathrm{Na}^{+}+\mathrm{K}^{+}+2 \mathrm{Mg}^{2+}+2 \mathrm{Ca}^{2+} \cdot \mathrm{TZ}^{-}=\mathrm{Cl}^{-}+\mathrm{HCO}_{3}^{-}+2 \mathrm{SO}_{4}^{2-}$.

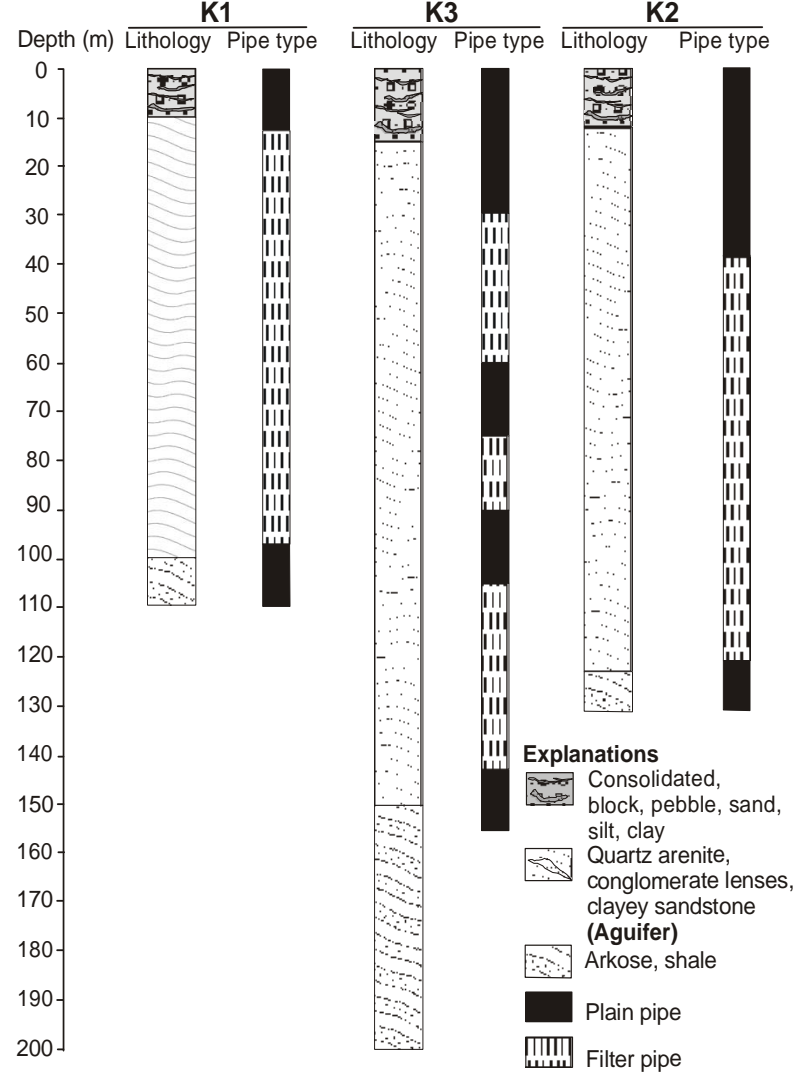

Figure 7. A general view of talus deposition.

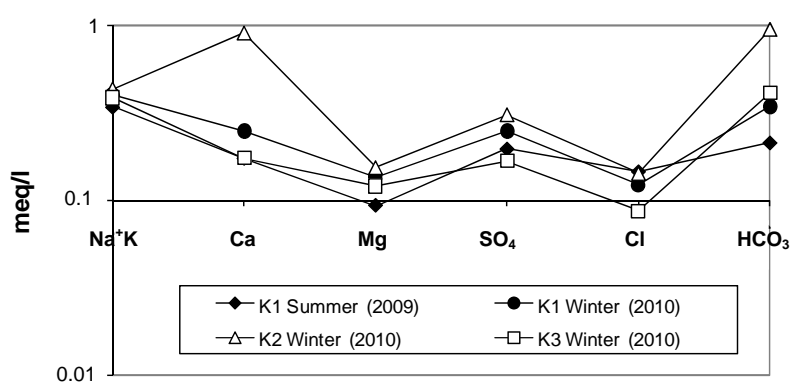

Figure 8. Schoeller diagram of the well water samples.

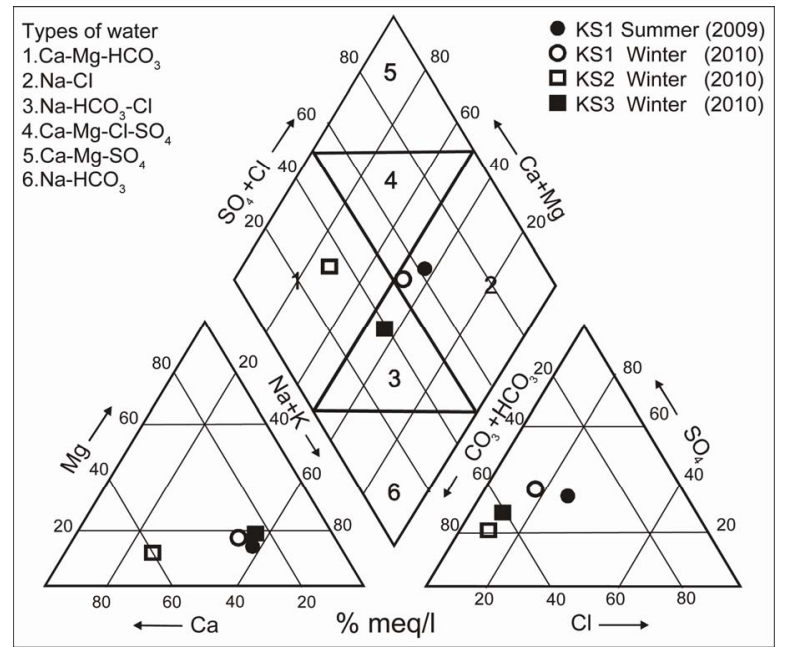

Figure 9. Piper diagram of the well water samples. 


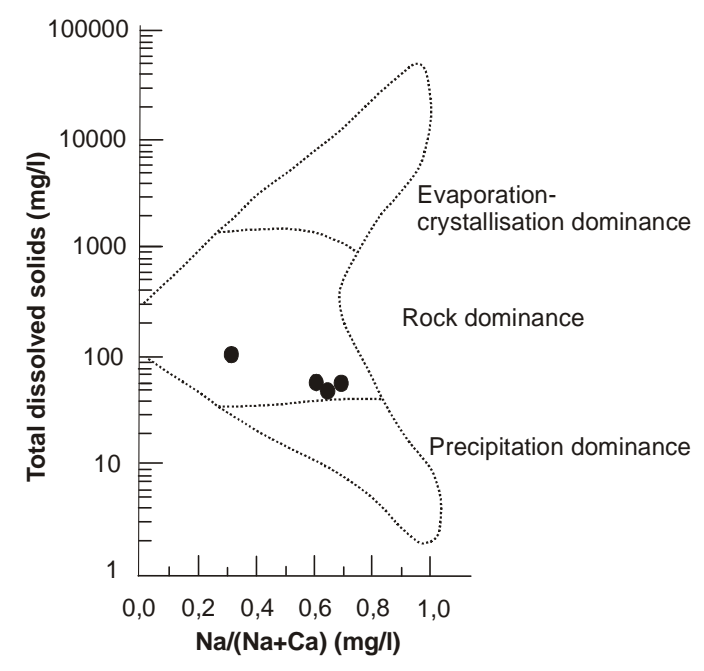

Figure 10. Gibbs diagram of the well water samples.

and cations: $\mathrm{r}\left(\mathrm{Na}^{+}+\mathrm{K}^{+}\right)>\mathrm{r}\left(\mathrm{Ca}^{2+}\right)>\mathrm{r}\left(\mathrm{Mg}^{2+}\right)$ and $\mathrm{r}\left(\mathrm{HCO}_{3}^{-}\right)$ $>\mathrm{r}\left(\mathrm{SO}_{4}^{2-}\right)>\mathrm{r}\left(\mathrm{Cl}^{-}\right)$. According to Schoeller diagram, the following proportions for summer and winter seasons of cations and anions of well waters are same, but deviation was determined for $\mathrm{Ca}^{2+}$ ion in winter season sample of KS2 well water. According to Piper digram, water types of well waters were determined as $\mathrm{Ca}^{2+}-\mathrm{Mg}^{2+}-\mathrm{HCO}_{3}^{-}$, $\mathrm{Na}^{+}-\mathrm{HCO}_{3}^{-}-\mathrm{Cl}^{-}$and $\mathrm{Na}^{+}-\mathrm{CI}^{-}$type. On the other hand, according to Gibbs diagram, well waters indicates interaction with rocks.

Most important factor in KS2 well water being rich in $\mathrm{Ca}^{2+}$ ions and the waters pumped out from quartzarenite aquifer exhibiting a distribution as if they belong to three different water types is the fact that water rock interaction of the excavation made at the talus deposit was affected the water chemistry.

Since the quartzarenites in the Camurluk stream basin are very hard and since the quartzarenite does not contain decomposable mineral, development of any change in chemical composition of underground water by water rock interaction does not become possible.

On the other hand, the surface water rich in ions that filtrates under influence of precipitation from the soil which has more elements compared to quartzarenite in geochemical respect, cannot pass into underground water. The barrier to this passing is the clayed levels rich in illite minerals contained in the talus deposit (and function as barrier) of surface water that became turbid during and after rains (Figure 2(b)). Because of this property, it becomes possible for Kuvars branded spring water to be offered for public consumption, being bottled after a simple filtration process. However, since natural course of hydrologic cycle has been changed by excavation process, in the waters of K2 and K3 wells near the excavation area, some major ion and heavy metal enrichments have been occured.

\subsection{Heavy Metal Content of Well Waters}

The results of heavy metal analysis of the spring waters taken from water wells are given in Table 4. According to analysis results, increments in the amounts of ions such as $\mathrm{As}^{3+}, \mathrm{Cu}^{2+}, \mathrm{Fe}^{2+}, \mathrm{Pb}^{2+}, \mathrm{Ag}^{3+}, \mathrm{Ni}^{2+}$ and $\mathrm{Si}^{4+}$ were determined in the well waters during transiton from arid to rainy season.

Among the ions that pass into well waters by waterrock interaction from outcropping rocks in the Camurluk basin during hydrolojic cycle, $\mathrm{Zn}^{2+}$ and $\mathrm{Al}^{3+}$ ions exceed the limit values permitted for drinking and spring waters by [22], $\mathrm{Pb}^{2+}$ ion exceeds the same permitted by [22,23, $27]$ and $[17,28], \mathrm{Ti}^{4+}$ ion exceeds the same permitted by [23] and $\mathrm{Fe}^{2+}$ ion exceeds the same permitted by [7] and Turkish Standard [17,28] (Table 5).

\section{Turbidity in the Well Waters}

In the excavation area, the turbidity values of the waters in the wells K2 (being operated) and K3 (will be put into operation) enriched with respect to suspended sediments (quartz and clay minerals) due to effect of precipitation, exceed the limit values allowed by World Health Organization (WHO), United Nations Environmental Protection Agency (EPA), European Union (EU) and Turkish Standards (TS) (Table 4).

The turbid water percolates downwards through the layers, cracks and joints of the quartzarenites underlying

Table 4. The results of heavy metal analysis (ppb) of the K1, $\mathrm{K} 2$ and $\mathrm{K} 3$ numbered well water samples in summer 2009 and winter 2010.

\begin{tabular}{|c|c|c|c|c|}
\hline Well no & K1 & K1 & K2 & K3 \\
\hline Sample no & $\begin{array}{l}\text { KS1 Summer } \\
(2009)\end{array}$ & $\begin{array}{l}\text { KS1 Winter } \\
\text { (2010) }\end{array}$ & $\begin{array}{c}\text { KS2 Winter } \\
\text { (2010) }\end{array}$ & $\begin{array}{c}\text { KS3Winter } \\
\text { (2010) }\end{array}$ \\
\hline $\mathbf{A l}^{3+}$ & 32.3 & 4.2 & 189 & 16.2 \\
\hline $\mathrm{Sb}^{3+}$ & $<0.10$ & $<0.10$ & $<0.10$ & $<0.10$ \\
\hline $\mathrm{As}^{3+}$ & 0.15 & 0.19 & 0.37 & $<0.10$ \\
\hline $\mathbf{B a}^{2+}$ & 26.8 & 20.2 & 28 & 13.9 \\
\hline $\mathbf{C d}^{2+}$ & $<0.05$ & $<0.05$ & 0.06 & $<0.05$ \\
\hline $\mathrm{Cr}^{3+}$ & $<0.50$ & $<0.50$ & 0.88 & $<0.50$ \\
\hline $\mathrm{Co}^{2+}$ & $<0.10$ & $<0.10$ & 0.30 & $<0.10$ \\
\hline $\mathrm{Cu}^{2+}$ & 1.93 & 2.11 & 1.76 & 6.27 \\
\hline $\mathbf{F e}^{2+}$ & 38 & $<30$ & 185 & 68 \\
\hline $\mathbf{P b}^{2+}$ & 0.18 & 0.64 & 59.4 & 1.29 \\
\hline $\mathbf{Z n}^{2+}$ & 8.8 & $<3$ & $<3$ & 25.5 \\
\hline $\mathbf{M n}^{2+}$ & 1.97 & 0.29 & 13.8 & 1.04 \\
\hline $\mathbf{H g}^{2+}$ & $<0.05$ & $<0.05$ & $<0.05$ & $<0.05$ \\
\hline $\mathbf{N i}^{2+}$ & 0.57 & 1.11 & 2.00 & 7.07 \\
\hline $\mathrm{Se}^{4+}$ & $<1$ & $<1$ & $<1$ & $<1$ \\
\hline $\mathbf{A g}^{3+}$ & 0.015 & 0.028 & 0.025 & 0.020 \\
\hline $\mathbf{T i}^{4+}$ & $<10$ & $<10$ & 12 & $<10$ \\
\hline $\mathbf{U}^{3+}$ & $<0.010$ & $<0.01$ & 0.049 & $<0.010$ \\
\hline $\mathrm{Si}^{4+}$ & 4710 & 5820 & 7440 & 6150 \\
\hline
\end{tabular}


Table 5. The limits permitted by the World Health Organization [22], European Union [27], United States Environmental Protection Agency [23], and Regulation [17] for drinking and natural waters (mg/l).

\begin{tabular}{ccccc}
\hline & $\begin{array}{c}\text { WHO 2006 } \\
\text { (Drinking } \\
\text { water) }\end{array}$ & $\begin{array}{c}\text { EPA 2009 } \\
\text { (Drinking } \\
\text { water) }\end{array}$ & $\begin{array}{c}\text { EU 98/83/EC } \\
\text { (Drinking } \\
\text { water) }\end{array}$ & $\begin{array}{c}\text { TS 266 and } \\
\text { RG25730 } \\
\text { (Spring water) }\end{array}$ \\
\hline $\mathbf{A l}^{3+}$ & 0.1 & 0.2 & 0.2 & 0.2 \\
$\mathbf{F e}^{2+}$ & 0.3 & 0.3 & 0.2 & 0.2 \\
$\mathbf{A s}^{3+}$ & 0.01 & 0.01 & 0.01 & 0.01 \\
$\mathbf{A g}^{3+}$ & 0.005 & 0.1 & $\mathrm{x}$ & $\mathrm{x}$ \\
$\mathbf{H g}^{2+}$ & 0.001 & 0.002 & 0.001 & 0.001 \\
$\mathbf{C o}^{2+}$ & $\mathrm{x}$ & $\mathrm{x}$ & $\mathrm{x}$ & $\mathrm{x}$ \\
$\mathbf{C d}^{2+}$ & 0.003 & 0.005 & 0.005 & 0.005 \\
$\mathbf{C r}^{3+}$ & 0.05 & 0.1 & 0.05 & 0.05 \\
$\mathbf{P b}^{2+}$ & 0.01 & 0.015 & 0.01 & 0.01 \\
$\mathbf{N i}^{2+}$ & 0.02 & $\mathrm{x}$ & 0.02 & 0.02 \\
$\mathbf{T i}^{4+}$ & $\mathrm{x}$ & 0.002 & $\mathrm{x}$ & $\mathrm{x}$ \\
$\mathbf{B a}^{2+}$ & 0.7 & 2.0 & $\mathrm{x}$ & $\mathrm{x}$ \\
$\mathbf{M n}^{2+}$ & 0.5 & 0.05 & 0.05 & 0.05 \\
$\mathbf{Z n}^{2+}$ & 0.01 & 5 & $\mathrm{x}$ & $\mathrm{x}$ \\
$\mathbf{C u}^{2+}$ & 2.0 & 1.3 & 2.0 & 2.0 \\
$\mathbf{S e}^{4+}$ & 0.01 & 0.05 & 0.01 & 0.01 \\
$\mathbf{S b}^{3+}$ & 0.005 & 0.006 & 0.005 & 0.005 \\
$\mathbf{U}^{3+}$ & 0.015 & 0.03 & $\mathrm{x}$ & $\mathrm{x}$ \\
$\mathbf{T} \mathbf{u r b i d i t y}^{3+}$ & $5 \mathrm{NTU}$ & $0.3 \mathrm{NTU}$ & $1 \mathrm{NTU}$ & $1 \mathrm{NTU}$ \\
\hline & & & &
\end{tabular}

the talus deposit. The turbid water has negatively influenced the quality of the well water K3. The turbid water has made unusable the submersible pump used for pumping out water from the well $\mathrm{K} 3$ being operated.

From the turbidity analyses made in 2009 and 2010 of the water of well $\mathrm{K} 1$, the turbidity value was determined as 0 NTU (Table 3).

\section{Results and Discussion}

According to Regulation of Water Pollution Control [29], Kuvars spring (bottled) water, which is filled at water production plant after it undergoes a simple filtration process and offered for public consumption, is classified as high quality underground water. Again according to the same regulation, the underground waters in the Camurluk stream basin are among the rare spring waters belonging the 1st class water quality characteristics in terms of formation, feeding, aquifer type, continuity of aquifer and geological and hydrogeochemical characteristics. The fact that the quality of these water may well degrade at any time was determined with the fact that excavation near $\mathrm{K} 1, \mathrm{~K} 2$ and $\mathrm{K} 2$ well locations has changed the natural course of hydrologic cycle. The excavation area is about 20 - 40 m away from $\mathrm{K} 1, \mathrm{~K} 2$ and $\mathrm{K} 3$ well waters.

Aquifer of the study area is covered by talus deposits. Its thickness is approximately $30 \mathrm{~m}$. Talus deposit contain clay layers and lens-shaped clay formations. On the talus deposit, only meadow has grown. The levels con- taining clayed sand and gravel have been well-consolidated. During the rainy period, the rainfall to the talus deposit cannot reach ground water within the aquifer (quartzarenite), unless any technical intervention such as excavation has been performed in the talus deposition. The vertical fault in the Camurluk stream basin is accumulate to the groundwater moving eastward within the quartzarenite. Therefore, water shortage may not be encountered at the water wells in the study area on the north of the fault (Figure 11).

Quartzarenite aquifer is fed by rainfall and infiltration. The amount of precipitation in the study area is 694.5 $\mathrm{mm}$. According to the [18] method, the potential evaporation value of the Camurluk stream basin was determined as $766.6 \mathrm{~mm}$ and the real one as $611.2 \mathrm{~mm}$. According to the water balance of the Camurluk stream basin, the amount of water that can be used reliably was calculated as $206,400 \mathrm{~m}^{3} /$ year.

The plagioclase mineral within the talus deposit was effective in the enrichment of $\mathrm{Ca}^{2+}$ ion in the water well sample taken from K2. Based on the heavy metals content of the well water of KS1, it was determined in the waters taken from the wells $\mathrm{KS} 2$ and $\mathrm{KS} 3$ that, some heavy metals such as $\mathrm{Al}^{3+}, \mathrm{Fe}^{2+}, \mathrm{Ni}^{2+}, \mathrm{Mn}^{2+}$ and $\mathrm{Cu}^{2+}$ have enriched in varying proportions in these wells. This increase in concentration was caused by interaction of the units belonging to talus left and released at the excavation area with 1 day severe precipitation.

The most important factors causing the chemical compositions of natural waters not change continuously during hydrologic cycle of natural waters in biosfer are the geological, structural and mineralogical controls [30, 31]. Storage (accumulation) of groundwater in joints and cracks of quartz arenite in the Camurluk stream basin and

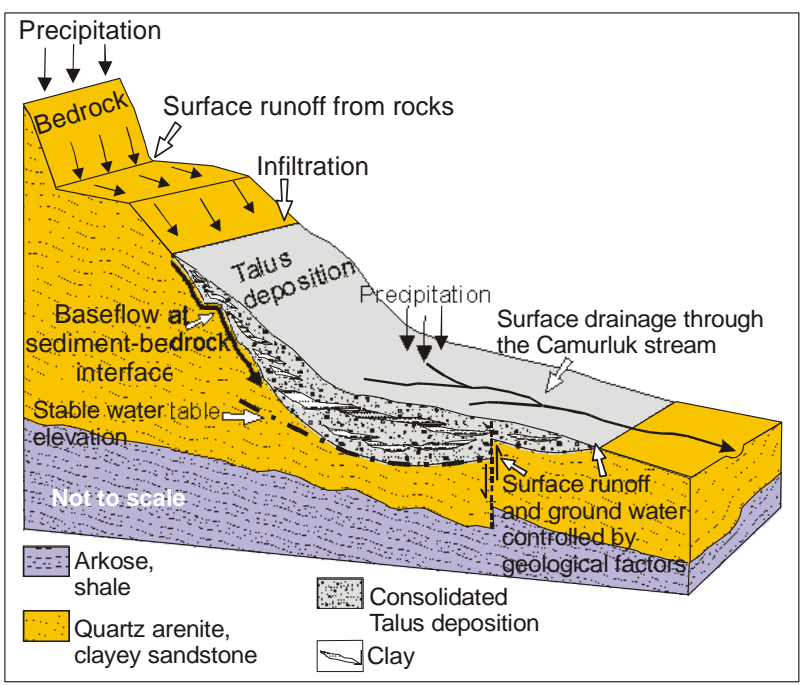

Figure 11. Schematic diagram showing the internal structure and groundmater and surface water flow pathways in the talus deposition (modified from [16]). 
chemical compositions of groundwaters not being negatively affected by talus deposit are owing to mineralogical composition of quartzarenite and clay levels and vertical fault in the study area (Figure 11).

Water-mineral interaction in the surface water that became turbid after a rainfall with the water-soil interaction at the excavation area, $\mathrm{Al}^{3+}$ concentration of 189 $\mathrm{ppb}(\mu \mathrm{g} / \mathrm{l})$ and $\mathrm{Fe}^{2+}$ concentration of $185 \mathrm{ppb}(\mu \mathrm{g} / \mathrm{l})$ detected in the KS2 well water (Table 4) proves that the drinking water limit value of $200 \mathrm{ppb}(\mu \mathrm{g} / \mathrm{l})$ permitted for $\mathrm{Al}^{3+}$ and $\mathrm{Fe}^{2+}$ ions by Regulation Concerning Water Intended for Human Consumption was approached. So, since upsetting the natural balance of talus deposit outcropping in the Camurluk stream basin shall negatively affect the quality of underground water, in order to people drink healthy water, such undertakings that shall disturb the stability of geological units should not be permitted.

\section{Acknowledgements}

This work was supported by Research Fund of the Istanbul University. Project number: 3934. The original manuscript was notably improved thanks to the comments and suggestions of two anonymous reviewers.

\section{REFERENCES}

[1] C. Lee and F. C. Loughnan, "Chemical Weathering of the Silicate Minerals,” Elsevier, London, 1969, pp. 1-154.

[2] R. J. Gibbs, "Mechanismis Controlling World Water Chemistry", Science, Vol. 170, No. 3962, 1970, pp. 10881090. doi:10.1126/science.170.3962.1088

[3] J. Gaillardet, B. Dupre and C. J. Allegre, "Geochemistry of Large River Suspended Sediments: Silicate Weathering or Recycling Tracer?", Geochimica et Cosmochimica Acta, Vol. 63, No. 23-24, 1999, pp. 4037-4051. doi:10.1016/S0016-7037(99)00307-5

[4] W. Chesworth, J. Dejou and P. Larroque, "The Weathering of Basalts and Relative Mobilities of the Major Elements at Belbex France," Geochimica et Cosmochimica Acta, Vol. 45, No. 7, 1991, pp. 1235-1243. doi:10.1016/0016-7037(81)90147-2

[5] R. F. Stallard, "Weathering and Erosion in the Humid Tropics," In: A. Lerman and M. Meybeck, Eds., Physical and Chemical Weathering in Geochemical Cycles, Kluwer Academic Publishers, Dordrecht, 1998, pp. 225-246.

[6] I. D. L. Foster and S. M. Charlesworth, "Heavy Metals in the Hydrological Cycle: Trends and Explanation," $\mathrm{Hy}$ drological Processes, Vol. 10, No. 2, 1996, pp. 227-261. doi:10.1002/(SICI)1099-1085(199602)10:2<227::AID-H YP357>3.0.CO;2-X

[7] N. A. Nkono and O. I. Asubiojo, "Trace Elments in Bottled and Soft Drinks in Nigeria: A Preliminary Study," The Science of the Total Environment, Vol. 208, No. 3, pp. 161-163. doi:10.1016/S0048-9697(97)00289-1

[8] C. Reimann, K. Bjorvatn, B. Frengstad, Z. Melaku, R. T.
Haimanot and U. Siewers, "Drinking Water Quality in the Ethiopian Section of the East African Rift Valley I-Data and Health Aspects," The Science of the Total Environment, Vol. 311, No. 1-3, 2003, pp. 65-80. doi:10.1016/S0048-9697(03)00137-2

[9] S. Li and Q. Zhang, "Geochemistry of the Upper Han River Basin China. 1: Spatial Distribution of Major İon Compositions and Their Controlling Factors," Applied Geochemistry, Vol. 23, No. 12, 2008, pp. 3535-3544. doi:10.1016/j.apgeochem.2008.08.012

[10] G. Papastergios, J. L. Fernandez-Turiel, A. Georgakopoulos and D. Gimeno, "Natural and Anthropogenic Effects on the Sediment Geochemistry of Nestos River Northern Greece," Environmental Geology, Vol. 58, No. 6, 2009, pp. 1361-1370. doi:10.1007/s00254-008-1639-8

[11] R. Pehlivan and O. Yilmaz, "Marmara Bolgesi Termomineral Kaynaklarinin İcilebilirligi ve İnsan Sagligina Etkisi," Jeoloji Muhendisligi Dergisi, Vol. 47, 1995, pp. 21-27.

[12] R. Pehlivan, "The Effects on Human Health and Hydrogeochemical Characteristics of the Kurkgecit and Ozancik Hot Springs Canakkale, Turkey," Environmental Geochemistry and Health, Vol. 25, No. 2, 2003, pp. 205-217. doi:10.1023/A:1023205900038

[13] R. Pehlivan "Quality of Bottled Waters in Turkey," Journal of Nepal Geological Society, Vol. 35, 2007, pp. 3742.

[14] C. Guler, M. Alpaslan and C. Akbulut, "Istanbul ve Civarinda Satisa Sunulan Sise Sularinin Kalitesi," Istanbul'un Su Politikasi Sempozyumu Bildiriler Kitabi, 2008, p. 408.

[15] R. Pehlivan, "The Effect of Weathering in the Buyukmelen River Basin on the Geochemistry of Suspended and Bed Sediments and the Hyrogeochemical Characteristics of River Water Duzce, Turkey," Journal of Asian Earth Sciences, Vol. 39, No. 1-2, 2010, pp. 62-75. doi:10.1016/j.jseaes.2010.02.011

[16] A. F. McClymont, M. Hayashi, L. R. Bentley, D. Muir and E. Ernst, "Groundwater Flow and Storage within an Alpine Meadow-Talus Complex," Hydrology and Earth System Sciences, Vol. 14, No. 6, 2010, pp. 859-872. doi:10.5194/hess-14-859-2010

[17] Regulation, "Insani Tuketim Amacli Sular Hakkinda Yonetmelik," Saglik Bakanligi, RG 25730, 2005, p. 27.

[18] C. W. Thornthwaite, "An Approach toward a Rational Classification of Climate," Geographic Review, Vol. 38, No. 1, 1948, pp. 55-94. doi:10.2307/210739

[19] DMI, "2009-2010 Y1lı Kumulatif Yagis Raporu. Devlet Meteoroloji Isleri Genel Mudurlugu," 2010.

http://www.dmi.gov.tr/veridegerlendirme/yagis-raporu.as $\mathrm{px} ? \mathrm{y}=\mathrm{k}$

[20] M. Onalan, "Istanbul Ordovisiyen ve Siluriyen İstifinin Cokelme Ortamlari," IU Yerbilimleri Dergisi, Vol. 2, No. 3-4, 1981, pp. 161-177.

[21] R. Pehlivan and O Yilmaz, "Hidrojeokimya," IU Muhendislik Fakultesi Yayin, No 112, ISBN No: 975-404 -750-2, 2005, p. 160.

[22] WHO, "Guidelines for Drinking-Water Quality, Recom- 
mendations," World Health Organization First Addendum to Third Edition Geneva, Vol. 1, 2006, p. 595.

[23] United States Environmental Protection Agency, "National Primary Drinking Water Ragulations,” 2009. http://www.epa.gov/safewater/contaminants/index.html

[24] J. Qin, Y. Huh, J. M. Edmond, G. Du and J. Ran, "Chemical and Physical Weathering in the Min Jiang, a Headwater Tributary of the Yangtze River," Chemical Geology, Vol. 227, No. 1-2, 2006, pp. 53-69. doi:10.1016/j.chemgeo.2005.09.011

[25] H. Schoeller, "Les Eaux Souterraines," Masson et Cie, Paris, Vol. 1, 1962, p. 642.

[26] A. M. Piper, "A Graphic Procedure in the Geochemical Interpretation of Water Analyses," US Geological Survey
Groundwater, Washington DC, Note 12, 1953, p. 63.

[27] European Union, “Council Directive 98/83/EC of 3 Nowember 1998 on the Quality of Water İntended for Human Consumption," Offical Journal, L330, 1998, pp. 32-54.

[28] Turkish Standard, "Sular-İnsani Tuketim Amacli Sular," TS 266, 2005, p. 10.

[29] SKKY, "Su Kirliligi Kontrolu Yonetmeligi," Cevre ve Orman Bakanligi, RG 25687, 2004, p. 51.

[30] P. W. Birkeland, "Soils and Geomorphology," Oxford University Press, New York, 1999.

[31] C. J. Bowser and B. F. Jones, "Mineralogic Controls on the Composition of Natural Waters Dominated by Silicate Hydrolysis," American Journal of Science, Vol. 302, No. 7, pp. 582-662. doi:10.2475/ajs.302.7.582 